\title{
Finding Space for Protection: An Inside Account of the Evolution of UNHCR’s Urban Refugee Policy
}

\author{
JEFF CRISP
}

\section{Abstract}

This article examines the evolution of UNHCR's urban refugee policy from the mid-199os to the present. It focuses on the complex and contested nature of the policymaking process, analyzing the roles that internal and external stakeholders have played in it. At the same time, the article identifies and examines key developments in UNHCR's operational environment that drove and constrained policymaking in this domain. The article is written from the perspective of a former UNHCR staff member who was substantively engaged in urban refugee policy.

\section{Résumé}

Cet article étudie lévolution de la politique urbaine relative aux réfugiés, menée par le HCR du milieu des années 90 à aujourd'hui. Il cible la nature complexe et contestée du processus de prise de décisions politiques, analysant le rôle joué de ce point de vue par différentes parties prenantes internes et externes. En même temps, il détermine et examine les évolutions clés de l'environnement opérationnel du HCR, qui ont été à la fois motrices et contraignantes vis-à-vis du processus de prise de décisions politiques dans ce domaine. Cet article est rédigé à partir de la perspective d'un ancien membre du personnel du HCR qui a été très engagé en matière de la politique urbaine relative aux réfugiés.

\section{Introduction}

uring the past two decades, the issue of urban refugees has occupied an increasingly important place on the global refugee policy agenda. This article traces the evolution of UNHCR's approach to the issue, focusing particularly on the complex and contested nature of the organization's policymaking process.

In that respect, the article examines the key drivers ofand constraints to-policy formulation during the period under review, examining the ways in which those drivers and constraints changed and interacted over time. The article also analyzes the role that different stakeholders, both internal and external to UNHCR, have played in policy formulation. As a result of these dynamics, the article concludes, the formulation of UNHCR policy on urban refugees has been slow and even tortuous.

The article is written from the perspective of a former UNHCR staff member who was extensively engaged in the organization's policymaking and who was responsible for researching and drafting its 2009 policy on refugee protection and solutions in urban areas. The following account draws extensively from the author's access to discussions, documents, and other information that have not been placed in the public domain. While striving for analytical and academic rigour, the article inevitably reflects the position, experiences, and personal views of the author.

\section{Origins of the 1997 Policy}

One of the first references to refugees in urban areas of developing countries appears in a 1967 statement by the un high commissioner for refugees, Prince Sadruddin Aga Khan. "We are confronted more and more frequently," he 
said, "with a new problem and with a new class of refugees: on the one hand, the students, who are to some extent the élite of the African refugees, and, on the other, refugees who are not employed in agriculture and who are at present concentrated in urban areas and in the big African capitals."

Despite this early identification of the urban refugee issue, it was not until the 1980 os and 1990 s that UNHCR, its governmental and non-governmental partners, and the academic community began to give this topic more concerted attention. The timing of that development can be attributed to four principal factors.

First, the number of urban refugees in developing countries was steadily growing, as was international awareness of their presence. Thus between 1984 and 1993, UNHCR undertook internal reviews of its assistance programs for urban refugees in a number of different locations, including Brazil, Guatemala, Mexico, Turkey, Zimbabwe, and several other African states.

Urban refugees also began to attract the attention of researchers and commentators, particularly in Africa. In 1976, Robert Chambers estimated the continent's urban refugee population to be in the region of 15,000 , but just three years later, Brian Neldner revised that figure to over 200,000. ${ }^{2}$

Certain urban refugee populations in Africa came under particular academic scrutiny. In 1979, for example, Louise Pirouet prepared a conference paper on urban refugees in the Kenyan capital of Nairobi. In 1985, Wendy Wallace drew attention to the growing number of refugees living in the Sudanese capital of Khartoum, an issue that was subsequently explored in greater detail by Gaim Kibreab. At the end of the 1980s, research undertaken by Derek Cooper began to explore the situation of refugees in Cairo, Egypt, while Marc Sommers and Roos Willems both turned their attention to exiles living in the Tanzanian capital of Dar-es-Salaam. ${ }^{3}$

Second, and as already indicated by Sadruddin Aga Khan in his 1967 statement, urban refugees were regarded and conceived as a problem, even by the most sympathetic commentators. Louise Pirouet, for example, who was an ardent advocate for refugee rights, made these observations in her 1979 paper on refugees in Nairobi, which was tellingly subtitled "Small Numbers, Large Problems":

Urban refugees are usually articulate, aware of at least some of their rights, and expect something more than mere subsistence

... They are able to organize themselves, and are therefore seen as a potential political danger ... The number of refugees in Nairobi has never been large. Yet the presence of only a few thousand refugees created large problems, swelling-as it did-the ranks of the urban poor with people who demanded that they should be helped to something better than mere survival in the Nairobi slums and shanty towns, thus arousing resentment among the Kenyan poor who could not even draw the minimum subsistence rates paid to refugees. 4

Third, while there might have been a growing awareness of urban refugees and the difficulties associated with them, UNHCR failed to develop an organizational policy or any operational guidelines in this domain.

In 1995, for example, an internal discussion paper observed, "Organizational policy regarding urban refugees is particularly weak and unclear, and practice, in terms of both protection and assistance, tends to vary substantially." Although reviews of the organization's urban refugee assistance programs had been undertaken throughout the previous decade, "their recommendations dealt exclusively with the specific objectives of the programmes under examination and made no reference to broader policy issues." The discussion paper consequently recommended "the establishment of a comprehensive policy on urban refugees."

A fourth driver of UNHCR policy at this time was funding. From 1989 onwards, UNHCR expanded very rapidly, largely as a result of new emergencies in the Balkans and Great Lakes region of Africa, as well as large-scale repatriation operations that became possible as armed conflicts in Southeast Asia, Southern Africa, and Central America came to an end. As a result of these developments, the organization's budget (most of which is provided by voluntary contributions from donor states) jumped from $\$ 570$ million in 1989 to $\$ 960$ million in 1996, an increase of 68 per cent. ${ }^{6}$

Within the organization, concerns were mounting about the sustainability of this growth pattern and a fear that UNHCR would soon be confronted with a serious financial shortfall. Thus at the opening of the 1996 meeting of the organization's governing body, the Executive Committee, High Commissioner Sadako Ogata said that while the projected budget for the coming year stood at $\$ 1.3$ billion, only $\$ 776$ million had actually been contributed. "I appeal especially to the donors here present," she said, "to make an extra effort for the serious shortfall in our operations."

As well as appealing for additional funds, the high commissioner initiated a campaign to find efficiency savings, and, in her words, "to deliver the changes necessary for UNHCR to perform better with less."7 In this context, urban refugee assistance budgets came under particularly close examination, partly because they had been steadily rising, but also because on a per capita basis they were thought to be far more expensive than supporting refugees in camps or rural settlements.

UNHCR's examination of its operational refugee budgets also revealed that a growing number of urban refugees were being given monthly cash handouts indefinitely and 
without obligation to establish a livelihood. Amongst many UNHCRstaff, there was a mounting perception that those refugees had succumbed to the "dependency syndrome," had developed an unwarranted sense of entitlement, and had no real incentive to become self-reliant. They had become, in a popular phrase at that time, "professional refugees."

\section{The 1997 Policy}

In response, UNHCR established an Urban Refugee Working Group, which in March 1997 produced a "comprehensive policy on urban refugees." The twenty-three-page document starts out conventionally and uncontroversially enough, observing that the principal objectives of the policy "are to ensure protection and to maximize access to solutions, both for individual refugees and for groups."

As it progresses, however, the policy places an increasingly exclusive emphasis on the difficulties and costs associated with the presence of refugees in urban areas. Urban refugees, it says, are "a global problem." Many urban refugees come from countries with "a long history of migration related to trade and/or a nomadic tradition," or "a history of economically-driven migration ... or have been involved in aliens trafficking."

Having raised such questions about their bona fides, the policy makes a series of negative generalizations about the world's urban refugees. They are "predominantly young, single (or separated) males." "While constituting less than two per cent of UNHCR's refugee caseload," they "demand a disproportionate amount (estimated at 10 to 15 per cent) of the organization's human and financial resources."

Donor states, the policy points out, "have become increasingly selective in terms of the programmes they support ... and show little enthusiasm for long-term care and maintenance of urban cases." As for the refugees themselves, "life in urban areas does not constitute an answer to their problem and may well be significantly more difficult than in a rural settlement."

Three issues feature particularly strongly in the 1997 policy. The first is that of "irregular movers," a topic that occupies no less than a quarter of the document. In contrast, the paper did not include a section on the application of UNHCR's protection mandate to refugees in urban contexts.

According to the policy paper, "a majority of urban cases" consist of refugees "who move in an irregular manner from countries in which they have already found protection in order to seek asylum or permanent settlement elsewhere." Such irregular movements are caused both by "push factors" in the country of first asylum ("intolerance, insecurity, poverty") and by "pull factors" in other states ("better economic conditions, higher levels of care and maintenance assistance, access to secondary and tertiary education, better resettlement opportunities").
While recognizing that "the right of refugees to effective and adequate protection is inviolate and is therefore not affected by irregular movement," the policy concludes that "UNHCR has an interest in the adoption of measures to reduce irregular movements."

A second dominant issue is that of assistance and self-reliance. In the words of the policy, refugees and asylum seekers arriving in urban areas "have often travelled long distances, using organized transportation as opposed to travelling on foot." "They have paid for their transport, food and lodgings needs en route. It should therefore not be assumed ... that he/she is necessarily destitute."

The policy goes on to suggest that providing long-term assistance to urban refugees "keeps them dependent and undermines their coping mechanisms, leading to marginalization, frustration and often violence. It also favours unjustly the individual treatment of urban cases compared to those in rural settlements and camps."

The third issue to emerge very strongly from the 1997 policy is that of security. In a section titled "Violence," the document states that "it is often those individuals who succeed in moving from one country to another... who become aggressive and violent if their expectations are not met." Amongst urban refugees, "hunger strikes, demonstrations, physical assault ... and suicide threats are now commonplace." Particular problems can be expected from "rejected cases, those refused assistance as well as the psychologically disturbed." "Giving in to violent forms of protest," the policy concludes, "does not pay, but on the contrary exacerbates long-term problems."

On the basis of this analysis, the 1997 paper sets out a number of policy provisions.

First, there is a "legitimate urban caseload," consisting of refugees who come from an urban background and have been recognized as refugees on an individual basis, as well as prima facie refugees who are obliged to take up residence in an urban area for security or protection. There might also be "rare exceptions" amongst the prima facie refugees who have to leave their camp or settlement temporarily and move to an urban area for education, medical care, or family reunion.

Second, while some members of the "legitimate" urban refugee caseload might require and be entitled to assistance, such support should be "strictly time-limited-no more than three months - and given with the objective of supporting a refugee's efforts towards self-sufficiency."

Third, refugees who are part of a prima facie caseload "for whom a UNHCR assistance programme exists in a rural camp or settlement ... should, as a general principle, not be provided with assistance." When such refugees cannot support themselves in an urban environment, "consideration should be given to transferring them to a rural camp or settlement." 
Fourth, refugees should "remain as close as possible to their country of origin." Irregular onward movements should be reduced, and arrangements should be introduced "for the return of refugees and asylum seekers to countries where they had or could have sought asylum."

Finally, when urban refugees engage in what are deemed to be illegitimate and violent protests, "it is not appropriate for UNHCR to intervene." "UNHCR staff should not hesitate to seek the intervention of the local authorities ... and call in the police."

\section{Reactions to the 1997 Policy}

While the 1997 paper filled an important gap in UNHCR's policy repertoire, it did not lay the issue of urban refugees to rest. Indeed, the new policy proved to be highly controversial and one that, in the words of one Human Rights Watch report, was "heavily criticized both internally and externally". The Human Rights Watch report went on to say that the purpose of the policy "was unabashedly to reduce programmes for urban refugees and to prevent refugees from locating to an urban environment." The policy "focuses almost exclusively on assistance and ignores the very real protection needs of refugees in urban areas." As far as UNHCR was concerned, urban refugees remain "a policy blind spot."9

Confronted with such antagonistic reactions, in December 1997 UNHCR hurriedly issued a revised version of the policy, the organization's protection responsibilities towards refugees in urban areas. ${ }^{10}$ But that did not satisfy the NGO community, which continued to complain that the document placed excessive emphasis on assistance to urban refugees and on the irregular nature of their movement to urban areas.

The issue came to a head in the third quarter of 1999, when NGO participants in a consultation meeting with UNHCR demanded to know what the organization's intentions were on its urban refugee policy. Thinking on his feet, a senior UNHCR official acknowledged the NGOs' concerns and made an unscheduled promise that the organization would undertake a thorough review and revision of the 1997 policy. He then turned to UNHCR's Evaluation and Policy Analysis Unit (EPAU) to undertake this task.

EPAU's capacity to assume this responsibility was limited. It was a relatively new entity, established in September 1998 and staffed by just three people, only one of whom had experience in evaluation and policy analysis.

EPAU also had other priorities to address. As well as reviewing UNHCR's urban refugee policy, the unit was asked to examine UNHCR's role in protracted refugee situations, its emergency response capacity, its engagement with internally displaced populations, and its community services. At the same time, EPAU was to strengthen UNHCR's evaluation methods and enhance the organization's cooperation with the academic and research communities. ${ }^{11}$

As a first step in its efforts to review UNHCR's urban refugee policy, in 2000 EPAU undertook a desk-based global survey, to identify key issues for further research and analysis. As a second step, and in the same year, a number of geographically diverse locations were selected for a more detailed review, based primarily on the size of their urban refugee populations. They included New Delhi, Cairo, Nairobi, and Bangkok, as well as Eastern Europe. ${ }^{12}$

The 2003 paper engaged directly with many of the NGos' criticisms that had been levelled at the 1997 policy. Specifically, it emphasized the need for UNHCR to develop a stronger protection focus in its work with refugees and, rebutting a key principle of the 1997 policy, argued that UNHCR's engagement with urban refugee populations must "go some way beyond providing the minimum level of support for the shortest possible time." In addition, the document placed new emphasis on the need for UNHCR to advocate on behalf of the civil and socio-economic rights of urban refugees and to provide substantive support to their cultural, social, recreational, and sporting activities.

While the 2003 EPAU paper was intended to provide the basis for a new urban refugee policy, it did not. As one external commentator observed, "Despite the clear recommendation of EPAU to withdraw the 1997 policy and to replace it with a version of these guiding principles and good practice, the draft document has never been made public and, as yet, languishes without adoption by UNHCR. In a statement to the 2004 Executive Committee meeting of UNHCR, the International Council of Voluntary Agencies (ICVA) expressed concern over the failure of UNHCR to accept the draft document as policy and to move forward. Indeed, while UNHCR has recognized the inadequacies of the 1997 policy, a more effective policy has yet to supersede it." ${ }^{14}$

In similar vein, Human Rights Watch expressed agreement with EPAU's conclusions, adding, "Unfortunately, EPAU's recommendations have not yet been implemented by UNHCR." ${ }^{15}$

\section{Policymaking Constraints}

UNHCR's unwillingness to endorse and formalize the guiding principles and good practices set out in the 2003 EPAU paper was the result of several factors. Most importantly, internal discussions revealed that the approach it proposed was too radical and rights-based for some managers and staff members, who continued to perceive urban refugees as a problem and the programs established for them as an expensive luxury, especially when compared to the supposed "efficiency" of camp-based approaches. ${ }^{16}$

In the course of those discussions, concerns were also expressed that the proposed guiding principles would 
antagonize refugee-hosting countries in developing regions, many of whom (as Pirouet had explained twenty years earlier) regarded the presence of refugees in urban areas as "a potential political danger." 17

The resistance of some UNHCR managers to EPAU's proposals also stemmed from a sense that the organization was being bullied and blackmailed by other stakeholders. On one hand, they felt that ICVA and other members of the NGO community were arrogant in their representations to UNHCR on this matter. On the other hand, they resented the fact that some urban refugee populations were resisting implementation of the 1997 policy.

In New Delhi, for example, assistance payments to urban refugees were drastically reduced from 1998 onwards, with the ostensible objective of bringing their "dependency syndrome" to an end and promoting their self-reliance. But the refugees themselves (primarily Afghans) felt that they had been the victims of a cost-cutting exercise and complained that their legal, social, and material status in India made it impossible for them to support themselves. The relationship between refugees and UNHCR in the Indian capital broke down, and violent protests ensued. ${ }^{18}$

In keeping with the "violence must not be allowed to pay" approach of the 1997/9 policy, some influential managers within the organization concluded that a robust approach was needed, rather than the more consensual one recommended by EPAU. Indeed, EPAU itself came under considerable criticism for its negative assessment of UNHCR's urban refugee programs, in addition to the fact that from 1999 onwards, all of the organization's evaluation reports were placed in the public domain and protected from editorial interference by senior management.

The lack of consensus within UNHCR at this time, which played a key role in obstructing the formulation of an entirely new urban refugee policy, was compounded by other factors.

The first was weak organizational leadership. Serving as UN high commissioner for refugees between 2001 and 2005, Ruud Lubbers, the former Dutch prime minister, did not prioritize the question of urban refugees and did not take a clear stand on the direction of UNHCR's urban refugee policy. Despite the very clear commitments made to review and revise the 1997 policy, the issue was left unresolved.

Second, UNHCR was not held accountable for its failure to meet those commitments. The NGO community periodically complained that the organization had failed to move forward in the way that had been promised to them, but they could bring little real pressure to bear on the organization's leadership. The Executive Committee, which in principle was better placed to require action from UNHCR on this matter, also chose to stand back from the impasse that had emerged.
Finally, UNHCR's failure to resolve the urban refugee issue in the first half of the 2000 s likely also owed something to personnel changes. Specifically, when the head of EPAU was seconded from UNHCR to another agency in 2004, the person chosen to replace him was the main author of the 1997 urban refugee policy.

Apparently concerned with the way in which EPAU's recent work had criticized and contradicted that policy, the incoming head of the unit initiated a new round of field missions and consultations in 2005 and 2006. When that initiative failed to produce a viable new policy, responsibility for the urban refugee issue was transferred to the Department for International Protection (DIP), which had never been comfortable with EPAU's increasingly influential role in formulation of global UNHCR policy. Once again, the unit's Guiding Principles and Good Practice paper was put to one side, and DIP began to prepare its own draft policy on urban refugees.

\section{New Policy Drivers}

From 1999 to 2005 , the constraints identified in the previous section of this article paralyzed policymaking within UNHCR. While the organization had clearly committed to review and revise its approach to the urban refugee issue, it was simply unable to reach closure on the matter. In the course of the 200os, however, some important new policy drivers were emerging-which eventually overcame the obstacles to the formulation of a new policy.

First, UNHCR was increasingly obliged to engage with refugees in countries where refugees were not compelled to live in camps. In this respect, the post-2003 exodus from war-torn Iraq was of particular significance. During this period, hundreds of thousands of Iraqis (the precise number was never verified) left their country of origin, most of them fleeing to Jordan, Lebanon, and Syria. Many had an urban and middle-class background, were well educated, and had no intention of living in a refugee camp. Instead, they rented and shared accommodation, dispersed throughout the cities and towns of their asylum countries. ${ }^{19}$

This settlement pattern also coincided with the preferences of those states. Having gone through very difficult experiences with the Palestinian refugees on their territory, Jordan, Lebanon, and Syria had no interest in having the Iraqi refugees concentrated in overcrowded locations where their frustration might take a threatening political form. As a result, no camps were established for them.

At the same time, and in other parts of the world, the notion of preventing the "irregular" movement of refugees from one country to another and from camps to urban areas-a primary component of the 1997 policy-were proving to be fanciful. 
A growing proportion of the world's refugees found themselves trapped in protracted displacement. Confronted with the prospect of being confined to camps for years on end, without access to land, livelihoods, or the labour market, and with declining levels of humanitarian assistance, refugees were increasingly "voting with their feet," ignoring the restrictions placed on their freedom of movement, and moving to countries and cities where they could eke out a living in the informal sector.

In Kenya, for example, the authorities maintained a formal policy of "strict encampment," requiring refugees to obtain authorization from the authorities and UNHCR if they wished to leave the organized settlements at Dadaab and Kakuma in the remote north of the country. ${ }^{20}$

In practice, however, growing numbers of refugees from Somalia and other parts of the Horn of Africa made their way to Nairobi, many of them taking up residence in the neighbourhood of Eastleigh. By the mid-20oos, the area had been dubbed "Little Mogadishu." This trend was in clear contradiction to UNHCR's plan to return prima facie refugees to organized camps and settlements.

Another new policy driver in the post-1997 era was to be found in the changing demographics of the urban refugee population and UNHCR's increased sensitivity to social diversity.

From the 1960s onwards, it had been article of faith in UNHCR that the vast majority of urban refugees were young, single, and able-bodied men, a self-selecting group who had the physical and mental attributes needed to survive in the city. But this stereotype was now being challenged. As the number of urban refugees expanded globally, a growing proportion of them came from other sections of the family and community. This was particularly the case with Iraqi refugees, among whom it was common for households to move as a whole, often using the family car as their means of transport. ${ }^{21}$

At the same time, UNHCR was becoming increasingly aware of the need to better understand the different social groups to be found within the refugee populations it was supporting. In the 1990s, the organization began to give much greater attention to the specific needs of refugee women and children, an approach that later evolved into a strategy known as Age, Gender, and Diversity Mainstreaming (AGDM).

Introduced in 2004, AGDM required UNHCR's field offices to be "aware of differences within their populations of concern," with particular attention to the situation of women and girls, men and boys, adolescents, older people, those with disabilities, and members of minority groups. ${ }^{22}$

Such concerns were largely absent from the 1997 urban refugee policy, which included a single paragraph on refugee women and self-sufficiency. In this respect, it became increasingly clear that a major policy revision would be required if UNHCR's commitment to AGDM was to be taken seriously.

UNHCR's new focus on social diversity came at a time when many other aspects of global refugee policy were being reconsidered, within and outside UNHCR. During the 1980 os and 199os, the default response to refugee emergencies had been to accommodate the new arrivals in camps, to sustain them with "care and maintenance" assistance programs, and to wait for the day when conditions improved in the country of origin. At that point, repatriation could be promoted and organized.

From the end of the 199os onwards, this model of refugee response was subject to sustained critique from UNHCR staff members, academic analysts, and advocates who drew attention to three issues: the adverse consequences of longterm encampment for people who found themselves trapped in protracted refugee situations; the growing mobility and agency of refugees and the determination of many to establish their own livelihoods rather than rely on assistance; and the inadequacies and dangers of an approach that placed primary emphasis on the early — and sometimes prematurerepatriation of refugees. ${ }^{23}$

Finally, the limitations of UNHCR's restrictive urban refugee policy were exposed when, in the final quarter of 2005 , refugees in Cairo launched a sit-in protest close to the organization's offices to draw attention to the daily difficulties with which they were confronted. On 30 December, Egyptian security personnel forcibly and brutally removed the refugees, twenty-eight of whom were killed in the operation.

According to one analysis of these events, UNHCR "adopted a hostile and confrontational attitude" towards the refugees, "issued statements that accused the protesters of everything from rumourmongering to outright deception," and adopted an attitude that "served to confirm the protesters' grievances and frustrations." 24

It was in this context that Antonio Guterres, a former prime minister of Portugal, was appointed to the position of un high commissioner for refugees in 2005. Assessing the challenges confronting him and his organization, Guterres reached a number of conclusions; first, that the organization's work had to be underpinned by a much better understanding of what he called "global mega-trends," including urbanization, international migration, and climate change; second, that UNHCR should work more actively to find solutions to refugee situations-and to engage refugees themselves more fully in that process; and third, that UNHCR's activities had to be more firmly based on fundamental human rights principles.

As the high commissioner said in a conversation with the author of this article, who in 2006 was appointed head of a new 
Policy Development and Evaluation Service (PDES), "We can no longer collude with states in confining refugees to camps and denying them the right to exercise freedom of movement."

Acting upon these conclusions, in 2007 Guterres initiated annual and multi-stakeholder consultations known as the High Commissioner's Dialogue on Protection Challenges. The first examined UNHCR's mandate for protection and solutions in international migration. The 2008 Dialogue addressed protracted refugee situations. And for 2009, Guterres decided that the issue for discussion should be urban refugees.

This placed the rest of the organization in a serious dilemma. Ten years previously, the organization had promised to thoroughly review and revise UNHCR's urban refugee policy. It had not attained that objective, despite several efforts to do so and in the face of constant pressure from the NGO community. There was now a serious risk that the high commissioner would have to convene his December 2009 Protection Dialogue without a new urban refugee policy being in place, a highly embarrassing scenario for the organization.

With time becoming increasingly short, swift action had to be taken. In July 2009, the assistant high commissioner for protection concluded that the latest draft policy paper prepared by DIP was not fit for the purpose. Following a major evaluation of UNHCR's work with Iraqi refugees in urban areas of the Middle East ${ }^{25}$ the head of PDES was asked to draft a new urban refugee policy in the following month. The resulting paper drew extensively from the Guiding Principles and Good Practice paper prepared by EPAU in 2003 and was issued as UNHCR's new policy in September 2009, two months ahead of the High Commissioner's Dialogue.

In addition to drawing heavily from the 2003 paper, the new policy incorporated many ideas and initiatives that had emerged in the field. Confronted with a growing number of urban refugees, and in the absence of clear directions from Headquarters, UNHCR staff had in many instances developed their own urban refugee strategies. In that respect, practice had run ahead of policy.

\section{The 2009 Policy}

In both tone and content, the 2009 urban refugee policy set out to dissociate itself as far as possible from its 1997 predecessor. In what almost amounted to an admission of failure, the new document stated, "Rapid urbanization is one the most significant 'mega-trends' confronting our planet today. It is also an issue that interacts with and reinforces many other global developments, including climate change, environmental degradation, volatile commodity prices, financial and economic instability, and the absence of decent work for growing numbers of young people. In this context, UNHCR has considered it essential to reconsider the organization's position on the issue of refugees in urban areas and to adopt an approach to this matter that is more positive, constructive and proactive than has been the case in the past." 26

"Urban areas," the policy went on to assert, "are a legitimate place for refugees to reside and to enjoy their rights." "The purpose of the policy is to create an environment that is conducive for refugee protection and solutions in urban areas." "The rights of refugees and UNHCR's responsibilities towards them are not affected by their location or their status in national legislation." In other words, UNHCR would endeavour to provide urban refugees with protection and solutions, even in countries that required refugees to live in camps and refused to recognize those who had previously found protection in other countries of asylum.

On the three issues that had dominated the 1997 policy, the new document attempted to tread a much more protection-sensitive path. Instead of focusing on the violent and disruptive nature of urban refugees, the 2009 policy placed much more emphasis on the need to develop better communications and more harmonious relations with them: "UNHCR's relationship with refugees in urban areas has on occasions been a tense one, characterized by a degree of mutual suspicion ... To counter such difficulties, UNHCR's community outreach and communications efforts will form part of a broader strategy to establish a constructive dialogue and positive partnership with refugees in urban areas."

While UNHCR senior management required some reference to onward movement, the words irregular and unregulated were studiously avoided, as was the issue of returning refugees to their countries of first asylum:

\footnotetext{
The issue of "secondary" or "onward" movements has proven to be a very complex and controversial one, and cannot be explored at length in this paper, which is focused on the issue of providing protection and solutions to refugees in urban areas. On one hand, attempts to identify refugees who have engaged in "unnecessary" onward movements and to return them to their country of first asylum are fraught with numerous practical problems and ethical dilemmas. On the other hand, there remains an unresolved debate on the meaning and measurement of "effective protection" and the circumstances under which it is legitimate for a refugee or asylum seeker to move from one country to another.
}

And while the 2009 document continued to emphasize the need to limit assistance to urban refugees and to promote their self-reliance, it did so in a way that gave much greater recognition to the complexity of these objectives and the prerequisites for them to be attained:

While it is usually taken for granted that camp-based refugees will receive indefinite assistance if they are unable to engage in 
agriculture and other economic activities, it is sometimes assumed that refugees in urban areas are able to cope in the absence of such support. That is not necessarily the case, especially in countries where refugees have no legal status or residency rights [and] are not allowed to engage in income-generating activities ... In circumstances such as these, particular care will be taken by UNHCR to identify those refugees who need support and to determine and provide the level of assistance they require. At the same time, host governments will be encouraged to remove any legal obstacles which prevent refugees from becoming self-reliant.

Finally, while the 1997 urban refugee policy had not included a section on the issue of protection, the 2009 document used the notion of "protection space" as its organizing principle. "When refugees take up residence in an urban area, whether or not this is approved by the authorities, UNHCR's primary objective will be to preserve and expand the amount of protection space available to them ... While the notion of protection space does not have a legal definition, it is a concept employed by the Office to denote the extent to which a conducive environment exists for the internationally recognized rights of refugees to be respected and their needs to be met."

\section{Implementation and Outstanding Issues}

With the personal backing of the high commissioner, dedicated financial support from the us government, and the general endorsement of the High Commissioner's Dialogue, the implementation of the 2009 policy has assumed a far more robust form than had been possible in the contested 1997 document.

In summary, an internal Urban Refugee Steering Group was established to oversee implementation of the new policy, an entity that was later expanded to include NGO representation. Evaluation and support missions were undertaken to eight countries with significant number of urban refugees, while in 2012 a global survey was undertaken to identify which elements of the new policy that were being implemented most effectively and consistently. ${ }^{27}$

An urban refugee learning program was established for UNHCR and partner staff, while operational guidelines were prepared for education, health, and livelihoods programs in urban areas. An "urban good practices" website was created to facilitate the exchange of ideas and information among humanitarian personnel in different cities around the world, ${ }^{28}$ while UNHCR staff, government, and NGO personnel were brought together in regional consultations, focusing on lessons learned and future strategies in relation to urban refugees. ${ }^{29}$

While this range of activities is emblematic of the importance that UNHCR has placed on its new urban refugee policy, it would be misleading to suggest that implementation has been problem-free.

First, UNHCR made no attempt to assess the financial and human resource implications of the new document prior to its introduction. A frequent complaint from the field has been that staff are expected to engage much more thoroughly with urban refugees, but have not been given the capacity to do so.

At the same time, donor states have complained that the opaque nature of UNHCR's budgets make it almost impossible to determine how much resource allocations for urban refugee programs have been adjusted in response to the new policy. In some countries with relatively large camp-based populations and a proportionately small number of urban refugees, UNHCR staff have questioned the wisdom of refocusing resources from the former to the latter.

Second, while UNHCR has been unambiguous in stating that the implementation of its urban refugee policy does not rely on the agreement of host states, those countries continue to influence the way that urban refugee issues are addressed. In Tajikistan, for example, a large proportion of the country's refugee population are forbidden by law from taking up residence in the capital city of Dushanbe. ${ }^{30}$ In Kenya, authorities have continued to express a strong preference for encampment and have been engaged in a periodic and brutal campaign to rid Nairobi of its Somali refugees and to relocate them-first to Dadaab and ultimately to their country of origin. ${ }^{31}$

Third, the 2009 policy recognized that UNHCR would have to find new ways to work in urban contexts, and in that respect set great store in the establishment of cooperative relationships with non-traditional partners, including mayors, municipal councils, civil society, and faith-based organizations, as well as development actors whose programs targeted the urban poor.

Progress in this respect has been slower and less substantive than anticipated, partly because of the unfamiliarity of such organizations to UNHCR staff, but also because urban refugees usually constitute a very small proportion-and a foreign proportion - of the urban poor. In Nairobi, for example, the refugee population is estimated to be 100,000 at most. But that figure has to be considered in relation to the fact that the city accommodates around 2.5 million slum dwellers, or 60 per cent of its population. In such contexts, asking non-traditional partners to take greater account of the urban refugee population is always going to be an uphill task. $^{32}$

Finally, while UNHCR and its partners have focused very intensively on implementation of the urban refugee policy during the past five years, the discourse on this matter has become progressively diffuse. 
On one hand, a new area of policymaking has emerged for the humanitarian needs of urban populations affected by armed conflict, civil unrest, natural disasters, and medical epidemics. Refugees have received little specific attention in this emerging area. At the same time, UNHCR and its partners are now complementing their attention to the issue of urban refugees with a more general focus on the situation of refugees who are living outside of camps.

This development is closely related to the eruption of the Syrian refugee situation in the Middle East-an emergency involving more than four million refugees, some 85 per cent of whom are living alongside members of the local population in urban, peri-urban, and rural areas of Egypt, Jordan, Lebanon, northern Iraq, and Turkey. While the 2009 policy was formulated on the assumption that the number of urban refugees would expand, it simply did not anticipate these events. ${ }^{33}$

And it is for exactly that reason that in 2014 UNHCR introduced a new policy on "alternatives to camps," "extending the principal objectives of the urban refugee policy to all operational contexts." ${ }^{34}$ In that respect, the 2009 document has had an influence that is much broader than anticipated by those responsible for its formulation.

\section{Conclusion}

The evolution of UNHCR's urban refugee policy provides insights into the way that the organization functions and, more specifically, the way in which its policymaking is influenced by competing entities within the institution, by the interests of different external stakeholders, and by broader operational and intellectual trends.

For future research, there is considerable scope for the drivers and constraints identified in this article to be applied to other policy areas and to other key actors in the global refugee regime.

With respect to UNHCR, for example, it would be of interest to know whether the slow and tortuous nature of policymaking in relation to urban refugees has also been manifested in other global issues, such as the organization's role in internally displaced people, stateless populations, and those affected by climate change and natural disasters. ${ }^{35}$

At the same time, our understanding of the way in which global refugee policy is formulated would benefit from a more concerted analysis of the role and influence of individual donor states, host countries, other international organizations, NGOs, and academics, as well as bodies such as the UNHCR Executive Committee, UN General Assembly, and Security Council.

While UNHCR enjoys significant autonomy in its policymaking and is not obliged to seek formal approval for the policy documents it produces, the organization has an evident interest in taking account of the opinions of these other stakeholders. The way in which these opinions are both solicited and brought to the attention of UNHCR's senior management is a subject worthy of further research.

\section{Notes}

1 Sadruddin Aga Khan, "Statement to the Third Committee of the United Nations General Assembly," 20 November 1967.

2 Robert Chambers, "Rural Refugees after Arusha" (unpublished, September 1976); Brian Neldner, "The Settlement of Rural Refugees in Africa," Disasters 3, no. 4 (1979): 393-402.

3 Louise Pirouet, "Urban Refugees in Nairobi: Small Numbers, Large Problems" (paper presented at the African Studies Association of the United Kingdom Annual Conference, 1979); Wendy Wallace, Gaining Ground: Refugees in Sudan (London: Euro Action ACORD, 1985); Gaim Kibreab, "Eritrean and Ethiopian Urban Refugees in Khartoum: What the Eye Refuses to See," African Studies Review 30, no. 3 (1996): 131-78; Derek Cooper, Urban Refugees: Ethiopians and Eritreans in Cairo (Cairo: American University of Cairo, 1992); Marc Sommers, Fear in Bongoland: Burundi Refugees in Urban Tanzania (New York: Berghahn, 2001); Roos Willems, "Embedding the Refugee Experience: Forced Migration and Social Networks in Dar Es Salaam, Tanzania" (PhD diss., University of Florida, 2003).

4 Pirouet, "Urban Refugees in Nairobi."

5 "UNHCR's Policy and Practice regarding Urban Refugees: A Discussion Paper," UNHCR Inspection and Evaluation Service, Geneva, 1995.

6 "Income and Expenditure for UNHCR: 1971-2010," Global Policy Forum, 2011, https://www.globalpolicy.org/component/ content/article/133-tables-and-charts/50474-income-andexpenditure-for-unhcr-1971-2010.html.

7 Sadako Ogata, "Opening Statement at the Forty-Seventh Session of the UNHCR Executive Committee," 7 October 1996.

8 "UNHCR Comprehensive Policy on Urban Refugees," UNHCR, Geneva, March 1997. All subsequent quotations in this section are drawn from this document.

9 Human Rights Watch, Hidden in Plain View: Refugees Living without Protection in Nairobi and Kampala (New York: HRW, 2002), 161.

10 "UNHCR Comprehensive Policy on Urban Refugees," UNHCR, Geneva, December 1997.

11 The context in which EPAU was established is examined in Jeff Crisp, "Thinking outside the Box: Evaluation and Humanitarian Action," Forced Migration Review 8 (August 2000): 4-7. See also Simon Lawry White, "Improving the Effectiveness of UNHCR's Evaluation Function," UNHCR, Geneva, September 2000.

12 See, for example, Stefan Sperl, "Evaluation of unHCR's Policy on Refugees in Urban Areas: A Case Study Review of Cairo," UNHCR Evaluation and Policy Analysis Unit, Geneva, 2001; Kemlin Furley, Naoko Obi, and Jeff Crisp, "Evaluation of UNHCR's Policy on Refugees in Urban Areas: 
Report of a Workshop, Moscow, March 2002," UnHCR Evaluation and Policy Analysis Unit, Geneva, 2002.

13 Naoko Obi and Jeff Crisp, "UnHCr Policy on Refugees in Urban Areas: Report of a UNHCR/NGO Workshop," UNHCR Evaluation and Policy Analysis Unit, Geneva, 2002; Obi and Crisp, "Protection, Solutions and Assistance for Refugees in Urban Areas: Guiding Principles and Good Practice," UNHCR Evaluation and Policy Analysis Unit, Geneva, 2003.

14 Sarah Dryden Petersen, "I Find Myself as Someone Who Is in the Forest: Urban Refugees as Agents of Social Change in Kampala, Uganda," Journal of Refugee Studies 19, no. 3 (2006): 384 .

15 Human Rights Watch, Hidden in Plain View, 161.

16 The internal divisions within UNHCR at this time are examined in Barb Wigley, "UNHCR's Organizational Culture," UNHCR Evaluation and Policy Analysis Unit, Geneva, 2005.

17 Pirouet, "Urban Refugees in Nairobi." While UNHCR has often been criticized for paying too much attention to the views of donor states, the organization's concern to maintain a close relationship with key refugee-hosting countries has been relatively neglected in the literature on the organization.

18 Naoko Obi and Jeff Crisp, "Evaluation of UnHCR's Policy on Refugees in Urban Areas: A Case Study Review of New Delhi," unhcr Evaluation and Policy Analysis Unit, Geneva, 2000.

19 Jeff Crisp, Jane Janz, Jose Riera, and Shahira Samy, "Surviving in the City: A Review of UNHCR's Operation for Iraqi Refugees in Urban Areas of Jordan, Lebanon and Syria," UnHCR Policy Development and Evaluation Service, Geneva, 2009.

20 Elizabeth Campbell, "Urban Refugees in Nairobi: Problems of Protection, Mechanisms of Survival, and Possibilities for Integration," Journal of Refugee Studies 19, no. 3 (2006): 396-413.

21 Crisp et al., "Surviving in the City."

22 Virginia Thomas and Tony Beck, "Changing the Way UNHCR Does Business? An Evaluation of the Age, Gender and Diversity Mainstreaming Strategy, 2004-2009," UNHCR Policy Development and Evaluation Service, 2010.

23 For example, Oliver Bakewell, "Repatriation and Self-Settled Refugees in Zambia: Bringing Solutions to the Wrong Problem," Journal of Refugee Studies 13, no. 4 (2000): 356-73; Cindy Horst, Transnational Nomads: How Somali Refugees Cope with Refugee Life in the Dadaab Camps of Kenya (New York: Berghahn, 2006); Katy Long and Jeff Crisp, "Migration, Mobility and Solutions: An Evolving Perspective," Forced Migration Review 35 (July 2010): 56-7; Nicholas Van Hear, "From Durable Solutions to Transnational Relations: Home and Exile among Refugee Diasporas," New Issues in Refugee Research 83 (March 2003).
24 Forced Migration and Refugee Studies Program, A Tragedy of Failures and False Expectations, American University in Cairo, 2006. See also Robert McKenzie, "Against Refugees: An Ethnology of Asylum-Seeking in Egypt" (PhD diss., School of Oriental and African Studies, 2015), chapter 6.

25 Crisp, "Surviving in the City."

26 "UNHCR Policy on Refugee Protection and Solutions in Urban Areas," UNHCR, Geneva, 2009. All subsequent quotations in this section are drawn from this document.

27 "Report on Policy Development and Evaluation to the UNHCR Executive Committee," UNHCR, Geneva, July 2013. See also MaryBeth Morand, Katherine Mahoney, Shaula Bellour, and Janice Rabkin, "The Implementation of UNHCR's Policy on Refugee Protection and Solutions in Urban Areas: Global Survey," UnHCR Policy Development and Evaluation Service, Geneva, 2013.

28 Good Practices for Urban Refugees, http://www.urbangoodpractices.org/.

29 These consultations covered Africa, the Americas, Asia, and Europe. Reports of the meetings are available under "Reports and Papers," http://www.unhcr.org/uk/evaluationand-research.html.

30 Angela Li Rosi, Marco Formisano, and Ljubo Jandrijasevic, "Lives in Limbo: A Review of the Implementation of UNHCR's Urban Refugee Policy in Tajikistan," UNHCR Policy Development and Evaluation Service, Geneva, 2011.

31 Elizabeth Campbell, Jeff Crisp, and Esther Kiragu, "Navigating Nairobi: A Review of the Implementation of UNHCR's Urban Refugee Policy in Kenya's Capital City," UnHCR Policy Development and Evaluation Service, Geneva, 2011.

32 Loren Landau and Roni Amit, "Wither Policy? Southern African Perspectives on Understanding Law, 'Refugee' Policy and Protection," Journal of Refugee Studies 27, no. 4 (2014): 534-52.

33 Jeff Crisp, Greg Garras, Jenny McAvoy, Ed Schenkenberg, Paul Spiegel, and Frances Voon, "From Slow Burn to Boiling Point: A Real-Time Review of UNHCR's Response to the Syrian Refugee Emergency," UNHCR Policy Development and Evaluation Service, Geneva, 2013.

34 "UnHCr Policy on Alternatives to Camps," UnHCR, Geneva, 2014.

35 As many of the key documents and discussions relating to UNHCR's policymaking processes are not in the public domain, research of this nature would evidently require the cooperation of former and serving staff members.

Jeff Crisp is an associate fellow at Chatham House and research associate at the Refugee Studies Centre, University of Oxford. The author may be contacted at jefferyfcrisp@gmail.com. 